\title{
Volunteer Tourism: At the Crossroads of Commercialization and Service?
}

\section{Introduction}

Volunteer tourism is rapidly becoming a vast and lucrative segment of the tourism market (Tomazos \& Butler, 2011). Recent estimates of the numbers of volunteer tourist participants put their number to an approximate 600,000 (TRAM, 2008; Tomazos \& Butler, 2009). In the UK alone there were around 120,000 volunteers taking a volunteer placement abroad (Jones, 2004), and that figure did not include volunteers who did not use the services of a volunteer tourism organisation. These organisations act as brokers of volunteering experiences and in 2008 there were 300 such listed organisations (TRAM, 2008; Tomazos and Butler, 2009). The monetary value of volunteer tourism is calculated at around $£ 1$ billion (TRAM, 2008: p43). This figure is considered to be rather conservative taking into account that it is only based on the placement fees and it does not include any other form of tourist receipts (Tomazos \& Butler, 2011). The organisations themselves, in their majority labelled as nonprofit organisations, advertise in order to attract volunteers who pay them in order to be recruited on a worthy project in a number of different countries (Callannan \& Thomas, 2005; Tomazos \& Butler, 2009) and become part of a new 'elite' of ethically driven and morally conscious tourists. This relatively new form of travel proposes to simultaneously meet a supply based demand for assistance, but also simultaneously satisfy a segment of tourist demand as well: delivering revenues and profits to the broker-organisations and convey an ethically sound message to the morally conscious or even altruistic tourist.

Volunteer tourism in its many facets and forms claims to offer transformational experiences for the participants and valuable output and yield for the causes it serves (Wearing, 2001; Tomazos \& Butler, 2009; Brown \& Lehto, 2005; Coghlan, 2006). At the same time many tour- operators, environmental and humanitarian NGOs and academic groups make money offering opportunities to participate in projects that can assist in community development, scientific research or ecological and cultural restoration (Wearing, 2004; Wight, 2003). These organisations vary in their size, provision and scope (Callanan \& Thomas, 2005; Tomazos \& Butelr, 2009).

This transaction poses several philosophical and ethical questions. Are the organisations unethical by making money from arrangements for people to go and provide assistance for a 
worthwhile cause? Is it just a case of 'enlightened self-interest'? The answers to these questions are subject to another set of factors relating to the value of the organisations' input and the price charged for their services. A simplistic view would be to say that monetary gain is inappropriate in the world of benevolent intentions. However, while there may be a mission to serve a cause, the organisation involved in undertaking the stated mission may be argued to have a financial bottom line which has to be protected. This article explores this transaction while at the same time it turns a critical glance at espoused destinations and beneficiaries of the participants' contributions. In other words this paper raises questions on the transparency of proceedings in terms of profit distribution and it highlights different practices in terms of disclosing how contributions and fees are being divided between the broker organisations and the projects they serve

To this end, first some background information on volunteer tourism is provided, setting the stage for the discussion. Second the concepts of entrepreneurial philanthropy and 'enlightened self-interest' are framed: Whether volunteer tourism is a case of enlightened self-interest for both the participants and the organisations involved. In the context of this discussion social enterprise and the creation of social capital are also discussed, before presenting the method applied in this study. Subsequently the results and findings are discussed, before major conclusions derived from the discussion are reviewed.

\section{Background}

Before entering into a meaningful discussion on volunteer tourism and its facets, it is necessary to clarify exactly what is understood by this term. According to Wearing (2001, p.1) the term volunteer tourist applies to those tourists who "...for various reasons volunteer in an organised way to undertake holidays that might involve aiding or alleviating the material poverty of some groups in society, the restoration of certain environments or research into aspects of society or environment". Another definition provided by Singh \& Singh (2001) sees volunteer tourism “..."...as being more of a conscientious practice of righteous tourism-one that comes closest to utopia. At best, it may be regarded as an altruistic form of tourism, which has the capacity to uphold the highest ideals, intrinsically interwoven in the tourism phenomenon" (as cited in Singh, 2004, p. 174). Integral to the definition of volunteer tourism is the absence of pay and participants often pay for the privilege of volunteering (Wearing, 2001; Ellis, 2003; Tomazos \& Butler, 2009). A percentage of this fee, that could vary from a one-off placement fee or a larger fee covering 
living expenses (Tomazos \& Butler, 2009) is expected to be used for the benefit of the cause or project the volunteer will work for, but this is not always the case (Tomazos \& Butler, 2009).At the time of writing, the volunteer tourism market is characterised by proliferation with various experiences being offered by an ever expanding market which in many cases is emulating the successful model of segmented, packaged holidays (Ellis, 2003; Tomazos \& Butler, 2009).

Inevitably due to its nature and popularity volunteer tourism has attracted significant research interest in recent years by researchers who have added to the myth and ambiguity surrounding volunteer tourism (Tomazos, 2009; 2010) by coining different terms to describe the same phenomenon. In the literature volunteer tourism is treated as 'volunteer vacation' (McMillon, Cutchins \& Geissinger, 2006), 'mini mission' (Brown \& Morrison, 2003), 'mission-lite' or 'pro poor tourism' (Ashley, Roe \& Goodwin, 2001; Hall, 2007), 'altruistic tourism' (Singh, 2002), 'service based vacation' (Ellis, 2003) and 'voluntourism' (The Guardian, 2007).

The above definitions, even though they do paint an ambiguous picture, they are clear in terms of portraying volunteer tourism as a tourism activity incorporating volunteer services (Tomazos \& Butler, 2011) i.e. enjoying a tourist experience with the benefit of helping others. The reciprocal nature of the volunteer tourist experience and the dynamics of service and instrumentalism as incorporated in the ethos of volunteer tourism allow for the phenomenon of volunteer tourism to be deconstructed as an example of enlightened self interest.

\section{Helping Yourself While Helping Others}

Throughout human history, there have been people who have found innovative ways to fulfil social needs (Bremmer, 2000). In this journey the concept of altruistic giving has evolved and has been expressed either as charitable giving or philanthropy. In terms of these two, there is a difference in terms of focus which sets them apart. On the one hand charity focuses on the immediate, symptomatic social problem i.e. feeding large numbers of homeless people or providing shelter for refugees. Philanthropy on the other hand is designed to achieve the actual socio-economic mobility of people (Acs, Phillips, Audretsch \& Desai, 2007) and it seeks to create long term improvement by empowering people. Charity, on its own, on the other hand is often seen as not providing a lasting solution and is argued to be harmful (Yunus, 2006; Dees, 2008). 
The rise of American philanthropists such as Carnegie and Rockerfeller Sr could be argued to be examples of what Marx and Engel described as 'self-serving philanthropy' (Wren \& Bedian, 2009). Organisations practice altruistic philanthropy for the singular goal of helping others and this so termed 'altruistic model' sees philanthropy as independent from the operational pressures of profit. Yet, noble as the cause may be the altruistic model alone does not explain the phenomenon of organised philanthropy, even in the most pluralistic of societies, because it ignores the motive or goal of profit maximisation (Neiheisel, 1994). The other model proposed and which is vital for the needs of this discussion is the profit maximisation model, which accepts that organised philanthropy is designed to contribute to direct monetary gain and is considered to be underpinned by the concept of 'enlightened selfinterest' (Drucker, 1984; 1981). This means that the organisation undertakes philanthropy as long as direct economic benefit can be gained by doing so (Bock et al, 1984). The concept itself was first discussed by Alexis de Tocqueville (1805-1859) in his work 'Democracy in America' (1835). The notion held that people join together in groups to further the interests of the group and by that serve their own interests. Drawing from the experience of the French Revolution and the Terror (Hutchins \& Adler, 1964) he suggested that by encouraging the masses to participate in civil associations, it would take their mind off the ills of their lives, but also by encouraging the aristocracy to contribute to the welfare and improving the life of the many, then they may minimise the risk of facing the guillotine again (Elazar, 1999).

In today's terms enlightened self-interest may be argued to take several forms and is inexorably linked to the concept of corporate social responsibility and the creation of social capital (Cooper \& Raiborn, 1974; Summers, 1974; Carroll, 1999; Margolis \& Walsh, 2001; 2003; McWilliams \& Siegel, 2001; Godfrey \& Hatch, 2007). Social capital as a notion has been around for a long time. The first use of the concept was in 1916 by L.J Hanifan, who highlighted the importance of community involvement for successful schools (Putnam, 2000). The concept though came into prominence thanks to the work of Jacobs (1961); Bourdieu (1983); Coleman (1988) and especially Putnam (1993; 2000). The creation of social capital can take place within organizational settings by increasing the ability to work together for common purposes in groups and organizations (Fukuyama, 1995). It can also be created by empowering otherwise disadvantaged participants to assume responsibility and control for their lives (Leadbeater, 1997). Such approaches may be argued to sit within the sphere of the third sector (Bornstein, 2004; Henton et al, 1997; Sullivan et al, 2003), including the social entrepreneurship domain (Zietlow, 2001; Thompson, 2002). This domain underlines the 
entrepreneurship and philanthropy nexus (Acs \& Philiips, 2000) which supports that successful entrepreneurs become philanthropists, directing their wealth at building social institutions that create opportunities, thereby lead to economic growth. Social entrepreneurs typically use market mechanisms to deliver a good or a service, in a highly effective fashion to a marginalised or poor population that would not have the same level of access to the good or service otherwise. Typically social enterprises combine lessons from the world of business and the world of civil society and benefit from the global exchange of expertise and access to networks. This approach means that the evolution of such approaches takes time and it is usually a case of trial and error as many successful social enterprise models pioneered in the last four decades evolved as the world was changing before becoming systematically globalised in the last decade (Lee, 2008; Campbell, 2008; Mickiewicz, Sauka \& Stephan, 2011). In many cases, such approaches are in general viewed as an expression of neo liberal free market ideologies, which prescribe to the notion that goods, services, experiences and even culture are commodified (Rifkin, 2000), so why not volunteer tourism? This commodification of volunteer tourism experiences means that volunteer tourism services/experiences have moved from having 'use value' for the participant or the beneficiaries to having 'exchange value' in the market place (Marx, 1867 in Wearing, McDonald and Ponting, 2005: 428). This process is reflected in the evolution and development of the contemporary volunteer tourism model which has been marked by the involvement of non-profit organisations.

\section{Not for Profit and Profit}

The third sector and its components have emerged to fill the gap between a reducing public sector and a price-focused private sector. "...Neither in the profit sector, nor the public sector, but between the two" (Wolfe, 1999: 20). The process of creating organizations within the voluntary sector is problematic as there is always suspicion regarding the purpose and responsibility of a non-profit organization in a context overshadowed by participative democracy, the stridency of profit-orientation, and a dramatically reduced level of state intervention (Fric, 1999: 4). Sentiments such as lack of trust, lack of personal self-confidence, mutual suspicion, and cynicism have added to the complexity of the task for non-profit organizations (Muller, 2003; Ladmanova, 2003).

Early economic theories on non-profit organisations in the literature (Feldstein, 1970; Hansmann, 1980; Ben-Ner, 1986) can be divided into two types: theories on the role of nonprofit institutions and theories on their behaviour. The first type deal with the reason behind 
the existence of non-profit organisations, and what functions they perform, while the second type address questions surrounding the objectives and the motivation of non-profit stakeholders. All non-profit organisations are subject to the laws of the country in which they were formed, normally involving a constraint of non-distribution (Hansmann, 1980) that prohibits the distribution of residual earnings to individuals who exercise control over the organisation, such as officers, directors or members (Hansmann, 1996). Non-profit organisations are not prohibited from earning profits per se, provided that they simply divert this surplus to supporting future services or distribute it to non- controlling persons. Non distribution of profits means that the organisations are barred from distributing 'net earnings' to individuals that exercise control over them (Steinberg and Gray, 1992), where 'net earnings are monetary gains in excess of the amount needed to pay services rendered to the organisations. In general a non- profit is free to pay reasonable compensation to any person for labour or capital that they provide, whether or not that person exercises control over the organisation. Without a doubt this is a very contentious term (reasonable compensation) because it is difficult to ascertain the point at which compensation ceases to be 'reasonable' and it becomes profit distribution. Examining the role of non-profit organisations in the general economic theory literature, it becomes apparent that non-profit organisations are viewed as private producers of public goods (Weisbrod, 1989; 1977). This means that such organisations exist to meet residual demand by providing public goods in order to supplement those provided by the government. In relation to this study, the volunteer tourism organisations provide assistance projects that could not sustain themselves solely on the resources provided by the public sector. What makes volunteer tourist organisations unique is the fact that while they meet a supply based demand for assistance, they also simultaneously satisfy a segment of tourist demand as well which leads to more profit driven practices and increasing commercialisation (Tomazos, 2009). These organisations supervise and train volunteers, allowing them to serve in a structured way and ensuring the safety and value of the experience. The volunteers on their side must pay for all their expenses, travel, board, lodging and in many cases also give a contribution. These donations are always tax deductible, further facilitating the act of giving. Some larger organisations have balances that are certified by auditing firms and they are available for examination in terms of establishing the destination of monetary contributions. Yet this is relatively rare and in most cases, it is not clear where or how the participants' fee is distributed (Tomazos and Butler, 2009). What is evidently clear though is that projects, especially in developing countries need a 
considerable amount of help in view of the very scarce resources to which they have access and the input of these organisations, commercial or not could be perceived as valuable.

\section{From Pacifism to Commercialisation}

The roots of volunteer tourism as a phenomenon can be traced back to the aftermath of World War One (Tomazos, 2009). The First World War brought with it levels of misery and destruction beyond that which had been previously encountered. This had a considerable impact on the psyche of ordinary people and paved the way for the birth of the phenomenon of volunteer tourism. The change in public mind set was reflected in an increased focus on peace rather than war and a desire to relieve suffering, which gave rise to the pacifist movement, including the International Fellowship of Reconciliation. In 1919 they organised an international conference in the Netherlands during which a Swiss man, Pierre Ceresole, presented the idea of an international team of volunteers who would work together to repair the damage from the war which had just finished. The idea was based on the premise that working together in a spirit of friendship would be an expression of solidarity which could heal the wounds of hate (Ceresole, 1954). In these times values determined by society, such as pacifism and to "help the wounded" became the instigation behind the phenomenon of volunteer tourism. Ceresole envisaged an outlet for human effort and ingenuity designed to alleviate pain rather than causing it. Similar motives of compassion drove Dunant to found the Red Cross a few years earlier (Boissier, 1985). Both the Red Cross movement and Ceresole's first work camps reflected a new drive towards peace initiatives. In the early 1960s US authorities were receiving worrying reports about Soviet university students travelling to developing countries and providing expert assistance. The fear of more countries falling under Soviet influence drove the Americans into action and the US Peace Corps were formed in order to win hearts and minds around the world. In his inaugural speech on 20th January 1961 President Kennedy issued a 'call to arms' for volunteers challenging a new generation of Americans “....to fight tyranny, poverty, disease, and war" and he also issued a pledge "....to those peoples in the huts and villages of half the globe struggling to break the bonds of mass misery" to help them help themselves (JFK quotes, 2007).

The Peace Corps began in 1961 with an executive order signed by President Kennedy which introduced it to the world as a volunteer organisation that would run on donated funds and funding by Congress. Within two years 7,300 volunteers were in the field serving in 44 countries from Afghanistan to Uruguay and by June 1966, more than 15,000 volunteers were 
working in the field, the largest number in the Peace Corps' history. Irrespective of the political agenda that lead to it, the founding of Peace Corps provided volunteer tourism with a model of international expansion and involvement at a large scale. This was generally adopted by volunteer tourism organisations, which became increasingly commercialised in their approach. At the time of writing, the volunteer tourism is in general unregulated and the only quality control mechanism available is the International Volunteering Program Association (IVPA) which is a membership body that provides a code of best practice, but has no power of enforcement (Tomazos and Butler, 2009). The IVPA highlight the importance of creation of public good by the organisations and their output and they have highlighted three elements of good practice; service, sensitivity and involvement (Tomazos, 2009: 107)

\section{Contribution of this Paper}

This paper highlights evidence from the literature relating to the following points:

1) The apparent increased commercialization of the volunteer tourism sector.

2) The potentially acceptable relationship between monetary gain and altruistic service within the third sector which is intrinsic to the supply of volunteer tourism opportunities

3) The continuous importance of the motivational element underpinning volunteer tourism organisations and the additional need to be competitive in terms of both monetary gain and the creation of social capital

This paper examines the volunteer tourism supply in order to gather evidence of commercialisation and profit driven behaviour, investigating a potential relationship between monetary gain and altruistic service, while collecting evidence assessing the extent to which volunteer tourism organisations identify a gap in provision and proceeds to meet such unmet needs, while offering the potential to build social capital.

\section{Method}

Following on from the work of Callanan and Thomas (2003), this paper utilises the existing data within the Volunteer Abroad Database to examine the nature of the market in volunteer tourism and to raise questions relating to any potential matches and mismatches between the data and the espoused approach on the part of volunteer tourism organisations. 
The Volunteer Abroad Database was selected as the source of data for this research as it provided the largest and most accessible level of content relating to available opportunities in volunteer tourism. Within the Database however there is a wide range of projects, not all of which meet the detailed criteria for categorization as volunteer tourism projects for the purposes of this research. In order to qualify as a valid project for this research the projects concerned were required to meet the criteria for tourism (less than 1 year more than 1 day and not constitute paid employment) and also the criteria for volunteering. All volunteer tourism projects encompassed by the Volunteer Abroad Database were therefore screened in order to clarify those projects which met the criteria required for categorization as volunteer tourism projects. Adventure holidays not involving volunteering were excluded, as were paid internships or work abroad opportunities and free places offered by religious organisations. The volunteer tourism projects thus identified were then categorised by: organisation, country, duration of project, type of activity and price.

Of 3,441 project entries identified in the database 995 did not meet the criteria for definition as volunteer tourism projects. They either exceeded a year in duration or were internships or paid jobs. This left 2,446 projects, which were then categorised into nine activity groups based on the work by Callannan and Thomas (2003). This subset of projects involved a total of 146 Volunteer Tourism Organisations. Based on the assumption that the identified projects were fuelled by local need, the 150 destination countries concerned were examined in terms of level of human development which was identified using their Human Development Index score. HDI scores are compiled using factors like GDP per capita, life expectancy, the quality of education and the literacy rate, to create a value where 1.0 is the highest possible score. Countries with an index above 0.8 are called 'high human development' countries; countries with indices between 0.799 and 0.5 are considered medium, while countries below 0.5 are categorized as low human development countries. The results of this analysis were considered relative to population size, in order to clarify whether population might be an influential variable.

In order to get a clearer picture of the value of the projects, in terms of output and added skills to the communities and causes they claimed to support, the top 40 volunteer tourism organisations, in terms of geographical expansion, were selected and an examination of their Web Sites was conducted in order to clarify their claimed status, stated policies and espoused practices. A coding system was developed to enable comparison across the organisations. The 40 organisations selected were examined in relation to key areas of interest based on the International Volunteer Programme Association (IVPA) criteria of ethical practice. The areas 
of interest for this research were: declared status, pricing policy, diversification (extras), screening of volunteers and involvement of locals (employment).

Due to obvious cost reasons the authors were not able to personally visit every project or organisation discussed in this paper. Instead they had to trust what the organisations declare on their websites.

\section{Findings and Discussion}

Foundation, Mission and Expansion

It is revealing that over half (26/40) of the organisations examined were founded by individuals, a figure head pioneer who set down the foundations of the organisation (see Table 1). The first was Pierre Ceresole, the man who started it all with the establishment of Service Civil International (SCI) (see earlier) in 1920. Brigadier Armstrong is another example who started the British Trust of Conservation Volunteers (BTCV) in 1959. The VSO also had similar beginnings with Alec and Moira Dickson being the founding figures. More recently Jean-Marc Arbeola started Volunteer Adventures in 1987; Dr Peter Slowe established Projects Abroad in 1992 and Deidre Bounds started I-to-I volunteers in 2003. Volunteer tourism organizations started growing significantly in numbers in the 1980s and then exploded in the 2000s. As presented in Figure 1 the period of the two World wars saw the emergence and development of 6 organisations, followed by the Cold War period and the Hippie (alternative) movement period during which ten new volunteer organisations came to existence. The 1980s brought an additional 13 volunteer organisations and in the 1990s another 32 followed, by the 2000s during which volunteer organisation numbers mushroomed. Out of the 146 organisations presented in the database, almost a third (46) were founded in the 2000s. Seventeen of these are in the top forty most expansive organisations. There are 38 organisations which did not state the year of their founding on their website.

\section{Declared Status}

In order to understand further how organizations gain and allocate their resources it is necessary to examine the status of the organizations and how they portray themselves. Table 2 shows that there are 17 of the 40 organizations studied that have non-profit status, and as such they are entitled to certain privileges which will be discussed below. In addition, there 
are 6 organizations that do not hold a non-profit status but instead make clear on their websites that they are operated by, or work for, non-profit organizations. Another 6 organizations call themselves "ethical NGOs" while a further 2 label themselves as charities. Different labels and different statuses involve different legal requirements, benefits and brand image. Three organizations made it clear on their website that they are 'special' tour operators organizing and packaging volunteer holidays. Finally there were 6 organizations that did not disclose their status on their website. This could be to avoid legal issues but the ambiguity might suit them.

What emerges from the above is that the market is characterised by inconsistency in terms of structure, commitment and mission. Non-profit status means that such organizations have a tax status meaning that any donations towards their projects are in general tax deductible for the donor and this may include participation and travel costs. Charities also hold a similar status with the added benefit that they can count on the support of national or international organizations. The brand and image value of being a non-profit or charitable organization is considerable. Organizations that are not recognised as such seem anxious to explain why they are making profits and why people should still choose them as their volunteer tourism provider. The general claim is that they only make an operating profit, which they argue enables them to continue the work they do. They further argue that they have a duty towards the projects they support, but also towards themselves and their families who must be supported through their salaries and wages. Other organizations refrain from declaring any status and thus do not have to explain or justify anything. However, all types of organizations claim to take the necessary steps to price their products and conduct their business ethically. Such statements are important as prices charged by the organisations are causing concern in the media at least (Times, 2008).

\section{Commercialization}

In terms of pricing, proliferation and variety are again apparent, with different organizations adopting different pricing strategies (Table 3). Starting with the cheapest projects, only one of the forty organizations examined offered volunteer projects for the price of a one-off application/membership fee. This fee was around \$500 US and it provided the opportunity to customers to choose another project without charge, as long as they wished to travel within the same year. There was also one organization that offered volunteer opportunities in return for a $\$ 1,500$ US deposit which participants could collect after completing their volunteer 
efforts. Three organizations refrained from disclosing any details about their volunteer opportunities. Instead they offered guidebooks for sale at prices ranging from $\$ 30$ to $\$ 75$. The vast majority of organizations, 25 out of 40, provided volunteer opportunities at a fixed rate with an all-inclusive packaged deal format. The fee in general included project fee, volunteer coordination, accommodation, and administration expenses. These fees range from $\$ 300$ US to \$1,000 US per week depending on destination, project, and of course, the type of accommodation.

Adding to the price of volunteer participation are certain extras which participants can purchase at their own discretion (see Table 4). These extras vary from short excursions and city tours to safari experiences. A recent development in the field is the option of obtaining academic credit, from mainly US academic institutions. The cost of such an optional extra varies from organization to organization and university to university. There were 10 organizations that would not disclose any details of this option on their website. Instead they offer a call-back service, perhaps in an attempt to utilize direct contact in recruiting new volunteers. It becomes apparent that the theme of ambiguity, uncertainty and proliferation exists in the pricing and packaging of most volunteer organizations. This may have certain implications in terms of the impact and contribution of the organizations to the destinations utilised.

\section{Rapid Expansion}

Not all countries in the world feature as volunteer tourist destinations. It is argued that the locations offered perhaps reflect a number of considerations of suppliers, including cost, appeal (as tourist destination) and need for assistance. The ten destinations with the highest number of projects are listed in Table 5. All countries in the list are categorized as developing countries, with India having 437 projects listed in the database. Compared to Callannan and Thomas (2003) count of 51, there was an increase of 386 projects in India within a period of four years. The second country on the list, South Africa had seen an increase of 377 projects, and Ecuador 329 projects. Overall in four years, the number of projects examined in 2003 (698) on the Volunteer Abroad database has increased to 6,059 in 2011, which is an increase of approximately 868 per cent in eight years, which confirms the rapid expansion hypothesis.

\section{Input and Impact}


Such variation in the market, in terms of size, ethos and business conduct, raises questions in relation to the value and utility of volunteer projects. Most organizations do their best to portray themselves as ethical improvers of communities and environments but the proliferation of approaches and ambiguity, plus the lack of control surrounding volunteer tourism leaves the door open for opportunists. There are some organizations that appear to have a clear mission and philosophy to international volunteering.

"Our conservation projects are established with the central aim of empowering local communities to manage their livelihoods sustainably, improving the overall quality of their lives and preventing over-use of their natural resources" (Organization 10)

Such commitment to their project and their impact is underlined by the fact that these conservation efforts are part of longer term programmes which may last up to five years. This commitment to projects does not seem to affect prices, since the organisation is able to offer projects for the relatively low price of \$ 125 US per week (excluding flights).

According to the International Volunteer Program Association (IVPA) essential requirements are a clear structure and understanding of the participants' roles and what should be expected from them. To that end some organizations offer training to their volunteers prior to departure and appear to have in place a rigorous selection program. Some organisations, for example appear to assess individual candidates before inviting them for a telephone interview. In the case of certain projects, some organisations run 'training weekends' which are held at least two months before departure. In general, organizations with clearly stated practices seem to put an emphasis on building their volunteering experiences upon the four element of good volunteer organization practice as prescribed by the IVPA code of ethics (ivpa.org) in order to maximise the impact of their projects (sensitivity, service, involvement, and long term viability) (see Figure 2). Sensitivity implies that organizations encourage their volunteers to be culturally sensitive and learn from their experience creating understanding and tolerance for other people and cultures. Organisations use their websites effectively in an attempt to convey that message:

"We believe that travel is about diversity. Travel is about authentic experiences and volunteering enables you to immense yourself in a foreign culture. Doing so will help you grow as an individual and will help you understand the importance of living in a world that is made colourful and vibrant by the many different cultures within it" (Organisation 5)

The second element, service, implies that the organisations are able and committed to provide good service to the project or cause of their choice. To this end there should be attempts to involve the locals as extensively as possible, creating employment and the conditions for long 
term viability by ensuring that the projects have the expertise and the infrastructure in place to enable them to continue, even without their contribution. Employment of local drivers, cooks, guards, game guards and boat crews contributes to the successful running of projects. Involvement of local scientists and students creates knowledge and experience that will remain even if volunteer tourism projects cease in an area.

Volunteers generally need to undergo certain training in order to be sensitive and good volunteers. Looking at the larger picture, in terms of training provided for participants, out of 40 organizations, only 16 made it clear on their websites that they provide training to prepare volunteers for their projects. This training varies from language training for volunteers in order to teach English as a foreign language (TEFL certification) to just being taught a local language at 'survival' level, and leadership training. Special projects involving diving may also provide PADI diving certificates for participant volunteers. In more general terms there are organizations (BTCV, Peace Corps) that provide basic manual labour training for volunteers who take part in conservation or construction projects. However, 24 of the organizations examined do not state clearly on their websites whether they offer any preproject training. Instead they offer the promise of pre-departure briefing material after registration with them. Other organizations advertise certain open-day events, but these could be seen more as recruiting than training events, since registration is not necessary in order to attend. This lack of mandatory training may reflect the simplicity of most volunteer project tasks, or it might also suggest avoidance of potentially costly practices by the organisations. This could have serious implication in relation to the impact of the projects but also the motivation of the volunteers in terms of how seriously they are taking their participation (Tomazos and Butler, 2011).

\section{Profit Distribution}

Out of the 40 organisations examined, only 18 had information on their websites in terms of where the participants' fee went. In general, on their websites organisations espouse that a percentage of the fee paid goes directly to the destination, normally to pay small, local suppliers for local transport, accommodation and food. The fee also covers support staff and sometimes there is a contribution towards the project placement. The rest of the fee is used to contribute towards other services required to offer a valuable experience (see Table 6).

There is a certain hesitation about providing direct monetary support to communities or projects which might stem from a perceived discomfort related to former colonial stereotyping. Volunteer tourism organizations generally profess a non-handout-policy 
because, as they describe in on their websites, they aim to create self-sufficient and sustainable projects in communities in need. On their website, for example, i-to-i stipulate that they avoid monetary handouts so that the projects “...do not become reliant on drip-fed financial aid for their continual existence" (Organization 35). They argue that direct financial contributions can have a destabilising effect on the development and spirit of communities. They continue with their argument that in case their involvement ceases "...the reasons can vary from an act of God, war, to a destination becoming less popular" (Organization 35) then a once relied on source of income is instantly removed and some of the projects would collapse. This echoes the argument made by Yunus (2006) that charity by its own as hand-outs could be harmful. Of course it is not known if the effect of such projects is always beneficial for the host communities and in many cases it is not clear if help is really needed (Tomazos \& Butler, 2009). It is not very clear to which extent the projects are 'rewarded' for taking on volunteers, but stories are resurfacing of projects taking on volunteers in order to receive payments, even though they had no need for their labour (The Times, 2011). This arguably causes resentment and ill feelings amongst the locals who find it impossible to compete with the volunteers in the labour market (Tomazos and Butler, 2011). This raises the alarm because, in theory, the need for their involvement could be simulated and thus they could be exploiting the participants, but this kind of cynicism prescribes that everything can be simulated.

\section{Creation of Social Capital}

In terms of the creation of social capital, defined as the creation of the circumstances for groups and organisations to work together and serve a common purspose, volunteer tourist organisations bring together, societal groups and people from different countries who work together in order to improve the lives of groups of people they would otherwise could not have impacted. In addition many organizations strive to keep their participants active and in touch after their return. Most encourage strong alumni networking and make full use of social networking websites as Facebook or Bebo. They arrange reunions and their offices help past volunteers get in touch with each other. In terms of future employment, references may be provided to prospective employers and university tutors. Organizations generally also tend to improve their 'product' by taking on board the feedback and constructive criticism of former participants, for example, by volunteers providing written feedback on their experience 


\section{Crossroads or Dead end Street?}

The above analysis has shown that the volunteer tourism market is prolific and it is expanding at a rapid rate. Examining the roots of organised volunteer tourism makes it impossible to overlook the role that individual initiative and business acumen has played in the development of structures and contemporary forms and this reflects the literature which supports that social entrepreneurs employ the entrepreneurial principles of the private sector into creating social goods. Its transformation into a bone fide business was probably inevitable due to the potential appeal of volunteer tourism products. The prospect of creating a business model or structure which could demand customers' time as well as physical labour along with their funds and provide them with a feeling of satisfaction and validation that they had contributed to a good cause could be argued to have proven irresistible for aspiring entrepreneurs (Tomazos and Butler, 2009). It could be argued that the mass-tourism model of packaging and segmentation now used in volunteer tourism was adopted because of its current success and popularity. Volunteer tourism has been segmented and packaged into its contemporary form (see Ellis, 2003). Through purposefully designed websites volunteer organisations ensure that volunteers are portrayed as the archetype of a new kind of tourist who has compassion and empathy for the plight of the disadvantaged, the neglected, the endangered and the needy, irrespective of species, situation or destination, an approach that has proven very successful. A significant segment of the volunteer organizations labels itself as non-profit. Yet the market is becoming more and more prolific with many organizations diversifying and offering various extras as part of the volunteering experience. Recently, there have been media calls for the volunteer organizations to stop charging large amounts of money for their services based on the argument that where there is a need volunteering and assisting should be free of charge (The Times, 2008). Volunteer Organizations now find themselves facing a dilemma as to which should be the way forward. Do they compromise and they accept that it is enough to be self-sustaining and happy to channel any modest profits back into their mission, or do they choose to seek opportunities of becoming commercially viable and thus tap into mainstream markets. Both approaches have their merits but also their drawbacks. On the one hand, the first approach fits the initial ethos and spirit of volunteer tourism, yet it means that the input of the organisation will always remain small, fragmented and capped by the restrains of limited resources. On the other hand, the second approach carries the promise of enhanced resources to serve the mission and create opportunities, provided that the organisation stays true to its non- profit mission. Evidence 
suggests that the choice between the two is not always straightforward. Having said that, it must be noted that, there are examples of organisations, which sit at the extreme ends of this spectrum of commercialisation and service; at the one end there are organisations that market themselves as ethical tour operators and they are registered as limited companies, while at the other end sit organisations which make no demands on the participants and they take upon themselves to cover all costs, focusing on their service mission. In general such organisations have a religious remit and they may receive funding from other external sources.

As it stands then, at the time being, volunteer tourism appears to be, just like any other economic activity, dependent on the availability of resources, which in this case are predominantly supplied by the participants and the reality is that organisations have to compete for these and this fact could prove to be very positive for the ethos of the sector. The positioning of organisations on the spectrum of commercialisation and service is likely to affect their efforts to attract the custom of an increasingly informed and sophisticated volunteer tourism customer base that are prepared to part with their money and offer their services, if they see that their efforts are making a difference. Yet what must not be overlooked is the fact that profit making practices that value profits over all things are threatening to take over every aspect of human endeavour (Capra, 2002) and undermine the ethos of social, cultural, environmental and humanitarian initiatives around the globe (Chomsky, 1999). Yes, such approaches create extra capital and supply extra resources, which if properly used, can make a difference, but is volunteer tourism selling its soul for market share? The rapid expansion of the sector stands witness on the effectiveness of applying market techniques to volunteer tourism, and the ambiguity, and inconsistency in terms of practices stands as a reminder of what happens to values or good intentions, once they are given an 'exchange value'. Future research will show, if volunteer tourism, not unlike Faust, has made the wrong bargain.

\section{Conclusion}

This paper has investigated the supply side of the volunteer tourism market within the context of its adopted business model which is central to the volunteer tourism providers' dynamic. In this environment the supply of volunteer tourism has evolved and been segmented in order to meet the requirements of operating within the not for profit sector but also meeting its responsibilities towards their staff and the projects they serve. The rapid expansion of volunteer tourism required injections of talent and capital and both can be problematic if 
commercial opportunities are not forthcoming or frowned upon. Volunteer tourism organisations had to survive in this environment and they evolved into hybrids of monetary gain and service blending business acumen with a social mission. This of course carries the risk of commercialisation contaminating the mission related activities with marketing philosophies with the result of the ethos of the mission being diluted. When Adam Smith was pointing out that business frequently serve the public good without having the specific intention to do so, it's impossible that he had volunteer tourism in mind but his quote really fits in the case of volunteer tourism. A social phenomenon that rose from the ashes of war inspired by the ideals of peace and brotherhood has evolved into a business phenomenon which is expanding at a rapid rate and becoming more and more commercialised. Volunteer tourism is here to stay and how valuable it will prove, especially in an era of cuts in terms of funding from the public sector, it remains to be seen. 


\section{$\underline{\text { List of References }}$}

Acs, Z.J., \& Phillips, R.J. (2000) "Entrepreneurship and Philanthropy in American Capitalism", Small Business Economics, 19.

Acs, Z.J., Phillips, R.J., Audretsch, D.B. \& Desai, S. (2007) "The EntrepreneurshipPhilanthropy Nexus: Nonmarket Source of American Entrepreneurial Capitalism", Paper 0907 on Entrepreneurship, Growth and Public Policy, Max Plank Institute of Economics

Ashley, C., Roe, D. \& Goodwin, H (2001) "Pro-poor tourism strategies: Making tourism work for the poor: A review of experience". Pro-poor report 1 for the ODI. Centre for Responsible Tourism

Ben- Ner, A. (1986) "Nonprofit Organisations: Why do they exist in Market Economies?" in Ackerman, R. ed "The Economics of Nonprofit Institutions". Oxford University Press, 94-113

Bock, B., Goldschmid, H.J., Millstein, I.M., \& Scherer, F.M. (1984) “The Impact of the Modern Corporation", Columbia University Press, New York

Boissier, P. (1985) “History of International Red Cross: From Solterino to Tsushima”, Henry Dunant Institute, Geneva

Bornstein, D. (2004), "How to Change the World: Social Entrepreneurs and the Power of New Ideas", Oxford University Press, New York, NY

Bourdieu, Pierre. 1983. "Forms of Capital." Pp. 241-58 in Handbook of Theory and Research for the Sociology of Education, edited by J. G. Richardson. New York: Greenwood.

Bremmer, R.H. (2000) “Charity and Philanthropy in History” Transaction Publishers, New Jersey

Brown, S., \& Lehto, X. (2005) "Travelling with a Purpose: Understanding the Motives and Benefits of Volunteer Vacationers ”, Current Issues in Tourism, 8 (6), 479-496.

Brown, S. \& Morrison, A. (2003) "Expanding Volunteer Vacation Participation: An Explanatory Study on the Mini-Mission Concept", Tourism Recreation Research, 28(3), 7382.

Callanan, M., \& Thomas, S. (2005). Deconstructing volunteer activities within a dynamic environment. In M. Novelli (Ed.), Niche tourism. Oxford: Elsevier; Butterworth and Heinemann.

Capra, F. (2002), "The Hidden Connections: A Science for Sustainable Living". Harper Collins. London

Carroll, A.B. (1999), "Corporate Social Responsibility: Evolution of a Definitional Construct”, Business and Society, 38 (3), 268-295 
Ceresole, P. (1954), “Une autre patrie” (Reprint). Le Service Civil, No.65, Bern (December) p 1

Chomsky, N. (1999), "Profits over People- Neoliberalism and the Global Order". Seven Stories. New York

Coghlan, A. (2006) "Volunteer tourism as an emerging trend or an expansion of ecotourism? A look at potential clients' perceptions of volunteer tourism organizations". International Journal of Nonprofit and Voluntary sector Marketing; Vol 11; issue 3, 225-237

Coleman, James S. 1988. "Social Capital in the Creation of Human Capital." American Journal of Sociology 94(supp.):S95-S120.

Cooper, S.K., \& Rairborn, M. (1974), “Accounting for Corporate Social Responsibility", MSU Business Topics, Vol 22 (2), 19-26

Dees, G.J. (2008) "Philanthropy and Enterprise: Harnessing the Power of Business and Social Entrepreneurship for Development" Innovations, Vol 3, (3), 119-132

Drucker, P.F. (1981), “Can there be "business ethics?" The Public Interest 63/2, 18-36.

Drucker, P.F. (1984), “The New Meaning of Corporate Social Responsibility”, California Management Review, Vol 40 (2), 53-64

Elazar, D.J. (1999) “Tocqueville and the Cultural Basis of American Democracy", Political Science and Politics, Vol 32 (2), 207-210

Ellis, C (2003) "Participatory Environmental Research in Tourism- A global View", Tourism Recreation Research, 28(3), 45-55.

Feldstein, M. S. "Corporate Taxation and Dividend Behavior." Rev. Econ. Studies 37 (January 1970): 57-72.

Fric, P. (1999) "Activities and Needs of non-profit Organizations in the Czech Republic: The Results of Quantitative Sociological Research”, ICN and Agnes. Prague.

Fukuyama, F. (1995) "Trust: The Social Virtues and the Creation of Prosperity”, Hamish Hamilton, London.

Godfrey, P.H., \& Hatch, N.W. (2007) "Researching Corporate Social Responsibility: An Agenda for the $21^{\text {st }}$ Century", Journal of Business Ethics, Vol 1 (1), Today's Ethical Issues: Perspectives from the Business Academic Community, 87-98

Hall, C.M. (2007). "Pro-poor Tourism: Who Benefits". Channel View Publications. NY

Hansman, H. (1980) “The Role of Nonprofit En-terprise," Yale Law J., Apr. 1980, 89(5), pp. 835-901. 
Hansman, H. (1996) "The Changing Roles of Public, Private, and Nonprofit Enterprise in Education, Health Care, anI Other Human Services," in Individual and social responsibility: Child care, education, medical care, and long-term care in America. Ed. Fuchs, V. Chicago: U. of Chicago Press, 1996, ch. 9.

Henton, D., Melville, J., \& Walesh, K. (1997). "The age of the civic entrepreneur: Restoring civil society and building economic community”. National Civic Review, 86: 149-156.

Hutchins, R. M., \& Adler M.J. (1964), “The Great Ideas of Today”.Chicago: Encyclopedia Britannica Press, 1964

Jacobs, Jane. 1961. “The Death and Life of Great American Cities". New York: Vintage Books.

Jones, A. (2004). Review of gap year provision. UK Department for Education and Skill. Research report RR555.

Ladmanova, M. (2003) "Hliaci psi demokracie: program Podpova nevladnich organizaci prosazujicich vereny zajem (Watchdogs of Society: Program Support for non-profit Organisations promoting Public Interest)", Grantis, Dec, pp8

Leadbeater, C. (1997) “The Rise of the Social Entrepreneur”, Demos, London

McWilliams, A. and Siegel, D. 2001. "Corporate social responsibility: A theory of the firm perspective”. Academy of Management Review, 26: 117-127.

Margolis, J.D., \& Walsh, J.P. (2001) "People and Profits: The Search for a Link between a Company's Social and Financial Performance", Lawrence Erlbaum Associates, Mahweh, New Jersey

Margolis, J.D., \& Walsh, J.P. (2002) "Misery Loves Companies: Whither Social Initiatives by Business", Administrative Science Quarterly 48, 268-305

Marx, K. (1867), “Capital (Trans. B. Fowkes) (vol. 1). Penguin. Hammondsworth

McMillon, B., Cutchins, D., \& Geissinger, A. (2006). "Volunteer Vacations (9th ed).

Chicago: IL:Chicago Review Press

Mickiewicz, T., Sauka, A., \& Stephan, U. (2011) "Entrepreneurship and Philanthropy after Socialism” Working Paper. Strategy and Innovation, OR1007

Muller, F. (2003) "Voluntary Approaches in Protection of Forests in Austria", Environmental Science and Policy, 6 (3): 261-269.

Neiheisel, S.R. (1994) “Corporate Strategy and the Politics of Goodwill”, Peter Lang, New York

Putnam, R.D. (1993) "The Prosperous Community: Social Capital and Public Life", American Prospect, 4:3. 
Putnam, R.D. (2000) "Bowling alone: The Collapse and Revival of American Community", Simon and Schuster. New York.

Rifkin, J. (2000) “The Age of Access" Bantum. New York

Singh, T.V. (2004) "New Horizons in Tourism: Strange Experiences and Stranger Practices”, Cabi, London.

Singh, S., \& Singh, T.V. (2001) "Pilgrimages to the Himalayas" in" New Horizons in Tourism: Strange Experiences and Stranger Practices, Cabi, London, 170.

Steinberg, R., and Gray, B. H. (1992). The Role of Non-profit Enterprise. In Hansmann Revisited, Working Paper 93-4, Indiana University Center on Philanthropy, Indianapolis, Indiana.

Sullivan Mort, G., Weerawardena, J., \& Carnegie, K. (2003). "Social entrepreneurship: Towards conceptualization”. International Journal of Nonprofit and Voluntary Sector Marketing, 8(1): 76-88.

Summers, A. (1974). "Hidden Charges: The Costs Corporations Don't Bear", Business and Society Review/ Innovation, 10, 85-90

Tocqueville, A de. (1853) "Democracy in America", University of Chicago Press, Chicago

The Times (2011) "Gap-year volunteers are charged thousands for pointless projects" 23/04/2011, p 61-62

Thompson, J.L. (2002), “The world of the social entrepreneur', International Journal of Public Sector Management, Vol. 15 Nos. 4/5, pp. 412-31.

Tomazos, K. (August 2009). Volunteer tourism an ambiguous phenomenon: An investigation in the demand and supply of volunteer tourism opportunities. Unpublished $\mathrm{PhD}$ thesis, University of Strathclyde Business School.

Tomazos, K., \& Butler, R. W. (2009). Volunteer tourism: the new ecotourism? Anatolia: An International Journal of Tourism and Hospitality Research, 1(20), 196-212.

Tomazos, K., \& Butler, R. W. (2010). The volunteer tourist as 'hero'. Current Issues in Tourism, 13(4), 363-380.

Tomazos, K., \& Butler, R., Volunteer tourists in the field: A question of balance?, Tourism Management (2011), doi:10.1016/j.tourman.2011.02.020

TRAM. (2008). Volunteer tourism: A global analysis. ATLAS. January report.

Wearing, S. (2001). Volunteer tourism, experiences that make a difference. Oxon: CABI Publishing.

Wearing, S. (2004). Examining best practice in volunteer tourism. In R. A. Stebbins, \& M. Graham (Eds.), Volunteering as leisure/leisure as volunteering: An international 
assessment (pp. 209e224). Wallingford: CABI.

Wearing, S., McDonald, M., and Ponting, J. (2005), "Building a Decommodified Research Paradigm in Tourism: The Contribution of NGOs", Journal of Sustainable Tourism, Vol 13 (5), :424-438

Weisbrod, B. (1977), "Toward a Theory of the Voluntary Nonprofit Sector in a Three-Sector Economy," in The voluntary nonprofit sector. Ed.: Weisbrod, B. Lexington, M. A: DC Heath, 1977, pp. 51-76.

Weisbrod, B. (1989), "Rewarding Performance That is Hard to Measure: The Private Nonprofit Sector," Sci-ence, May 5, 1989, 244, pp. 541-46.

Wight, P (2003) “Ecotourism: Ethics or Eco-sell?” Journal of Travel Research, 31, (3), 3-9.

Wolfe, D.A. (1999) "Social Capital and Cluster Development in Learning Regions" in

"Knowledge, Clusters and Learning Regions", ed Holbrook, A.J., \& Wolfe, D.A (1999)

School of Policy Studies, Queen's University

Wren, D.A and Bedian, A.G 2009, "The Evolution of Management Thought", 6th ed., Wiley, Hoboken NJ.

Yunus, M. (2006) "Social Business Entrepreneurs are the Solution" Presented at the Skoll World Forum on Social Entrepreneurship, Said Business School, Oxford University,March 29 - 31, 2006

Zietlow, J.T. (2001) "Social Entrepreneurship: Managerial Finance and Marketing Perspectives", Journal of Non-profit and Public Sector Marketing, 9(112): 19-44. 
Tables

Table 1: Founders

\begin{tabular}{|l|l|l|}
\hline ORGANISATION & YEAR & FOUNDERS \\
\hline Service Civil International & 1920 & Pierre Ceresole \\
\hline Voluntary Service Overseas & 1958 & Alec and Mora Dickson \\
\hline Operation Crossroads Africa & 1958 & Dr James Robinson \\
\hline BTCV & 1959 & Brigadier Armstrong \\
\hline Amigos de las Americas & 1965 & Guy Bevil \\
\hline Earthwatch & 1971 & Max Nicholson \\
\hline Volunteers for Peace & 1982 & Peter Coldwell \\
\hline Global Volunteers & 1984 & Michel Gran and Bud Philbrook \\
\hline World Teach & 1986 & Michael Kremer \\
\hline Volunteer Adventures & 1987 & Jean-Marc Alberola \\
\hline Projects Abroad & 1992 & Dr Peter Slowe \\
\hline Greenforce & 1992 & Marcus Watts \\
\hline Cross-Cultural Solutions & 1997 & Steve Rosenthal \\
\hline Global Vision International & 1998 & Steve Gwenin \\
\hline United Planet & 1998 & Charles F. Clarke \\
\hline Helping Hand USA & 1999 & Mel W. Slavick and Frank Cook \\
\hline Global Volunteers Network & 2000 & Colin Salisbury \\
\hline Cosmic Volunteers & 2000 & Scott Burke \\
\hline Right to Play & 2001 & Johan Olar Koss \\
\hline Mondochallenge & 2001 & Anthony Lunch \\
\hline i-to-i & 2003 & Deidre Bounds \\
\hline Global Aware & 2003 & Haley Coleman \\
\hline Global Youth Opportunity & 2005 & Michelle L. Anderson \\
\hline
\end{tabular}

Source: Author's Analysis of Volunteer Abroad Database

Table 2: Declared Status

\begin{tabular}{|l|c|}
\hline \multicolumn{1}{|c|}{ Status } & $\begin{array}{c}\text { Number of } \\
\text { Organisations }\end{array}$ \\
\hline Not for Profit & 17 \\
\hline Operated by or working for non profit & 6 \\
\hline Ethical NGO & 6 \\
\hline Not Stated & 6 \\
\hline Special Tour Operator & 3 \\
\hline Charity & 2 \\
\hline
\end{tabular}

Source: Author's Analysis of Volunteer Abroad Database

Table 3: Pricing Policy

\begin{tabular}{|l|c|}
\hline \multicolumn{1}{|c|}{ Pricing Policy } & $\begin{array}{c}\text { Number of } \\
\text { Organisations }\end{array}$ \\
\hline Fixed Price & 25 \\
\hline Not Clear (Call back service) & 10 \\
\hline No prices & 3 \\
\hline Single Application Fee & 1 \\
\hline Deposit & 1 \\
\hline
\end{tabular}

Source: Author's Analysis of Volunteer Abroad Database 
Table 4: Extras on Offer

\begin{tabular}{|l|c|}
\hline \multicolumn{1}{|c|}{ Extra Options } & $\begin{array}{c}\text { Number of } \\
\text { Organisations }\end{array}$ \\
\hline Extra Supplements & 20 \\
\hline Not Stated (Call back service) & 10 \\
\hline Academic Credit & 8 \\
\hline No Extras & 2 \\
\hline
\end{tabular}

Source: Author's Analysis of Volunteer Abroad Database

Table 5: Rapid Expansion

\begin{tabular}{|l|c|c|c|c|}
\hline Country & Projects 2011 & Projects 2007 & Projects 2005 & Projects in 2003 \\
\hline India & 437 & 241 & 185 & 51 \\
\hline South Africa & 380 & 148 & 135 & 3 \\
\hline Ecuador & 376 & 188 & 150 & 47 \\
\hline Ghana & 366 & 171 & 149 & 37 \\
\hline Costa Rica & 353 & 201 & 133 & 43 \\
\hline Peru & 333 & 193 & 122 & 1 \\
\hline Kenya & 321 & 183 & 102 & 21 \\
\hline Thailand & 319 & 176 & 138 & 3 \\
\hline Nepal & 298 & 144 & 117 & 2 \\
\hline Brazil & 151 & 96 & 91 & 15 \\
\hline Totals & $\mathbf{3 3 3 4}$ & $\mathbf{1 7 4 1}$ & $\mathbf{1 3 2 2}$ & $\mathbf{2 2 3}$ \\
\hline
\end{tabular}

Source: Author's Analysis of Volunteer Abroad Database 
